\title{
SOLUTIONS FOR TEST OF SUPREM PENETRATION ABILITY OF COMPETITORS ON INTERNATIONAL MARKETS
}

\author{
Associate Professor PhD Cenar Iuliana \\ "1 Decembrie 1918” University Alba Iulia \\ cenar_iuliana@yahoo.com
}

\begin{abstract}
Globalization is a phenomenon that occurs extensively in the current period. This process entails extensive and the need to consider that entities survival depends on the ability to access external markets. The paper forms by diagnosis internationalization of entities pretense ways of access external markets, of course each with strengths and weaknesses. I considered that such a measure is useful to any entity that and NNRTI survival wants a competitive environment bitter.
\end{abstract}

Key words: globalization, entities survival, competitive ability, strategy

Jel codes: M31

\section{Internationalization and the option for survival entities}

Internationalization means for determining the phenomenon of reducing the national process of increasing its business involvement in international operations. Germinal incentives for internationalization are the excess resources or non-use of existing parts. In addition, business development at the international level makes the whole more than the existence of the entity, which must meet the requirements of globalization.

The international market is where it sells goods and services made in various national economies and where other economic activities carried out in various forms with a wide range of means and techniques.

An entity enters the market when they undertake active and long-term with its products on one or more target foreign markets, which initially has no activity and market targets. Penetration market refers to the ease or difficulty with which an entity can become a member of a group of companies competing by developing a close substitute for the products they offer. Basically, it comes to development products, asset management activities and new markets that pervade, the exposure of powers in a new area of activity.

Environment in which entities will act as a whole should be perceived factors such as economic, social, cultural, legal, etc.., A network of exogenous variables in the opposite which found its own human resources, materials and financial forms endogenous variables.

Its ability to identify and capitalize on market opportunities and ability to respond to adverse situations faced are essential to achieve targeted levels of performance. Also, in the process of internationalization approach entities to be targeted based on a long-term vision on its evolution and a coherent strategy.

Heterogeneity is the essential feature of the international market. Among the generators of its find: the diversity of goods, services, capital and ideas that form the subject of market relations, the extreme high of participants to exchange documents, the specific marketing.

The success of entering international markets is dependent on variables such as the ability to use the opportunities for profitable market penetration, access to productive resources, markets, overcoming barriers of entry on the market. 
Penetration of international markets is a strategy of diversification which is expected to generate profitable growth.

\section{Motivations internationalization}

Motivation is the result of ambiguous connotations and attractive at the same time, pointing to the secret hope to enter into resorts intimate conduct of others, a handle and shape.

In the process of building the premises goals for internationalization intervening two variables motivational, and motivations of reactive and proactive.

In the first case, the motivations reactive referring to the side of the body's response to the pressures coming on to the business environment in which they operate. Basically, there is the pressure of competition, low sales on the domestic market, non-use full production capacity, and overproduction and, of course, and the intention of nearby customers.

Motivations proactive engagement is based voluntary firms in international affairs in order recovery of strategic advantages, competitive or comparative (retroactive). Among the factors that generate motivations proactive mention access to resources, reducing costs through the benefits, valuing technology available. Are not neglected shift towards market management, expanding the network of information and communications in terms of globalization.

\section{Addressing the panoply of strategic options to access external markets}

Economic strategy the company is the determination of goals and long-term objectives, the means of action and resources needed (Alfred Chandler).

The development entity is subject to the choice of markets to be attractive and the option of entering foreign markets. In turn, these Conditions are affected by rising dynamics Environmental marketing, shortening the life cycles of products, increased research and development costs, compress time interval between the launch of a product and the emergence imitations, rising innovative processes etc.

Of course that the decision to enter the international market has a number of legal implications is subject to risks and expectations of future yield, so the options which we referred to above are not always easy.

The decision on the choice of how to access external markets is the result of the consideration selected the following groups of factors: marketing strategy, organization-specific variables, variables and the target country variables sector activity.

The strategy of internationalization is determined by the following ${ }^{1}$ :

- external data analysis (solvent demand, competition, constraints market access, the country risks) and its potential (aspirations, resources available, distinctive advantages such as production, marketing, and financial);

- determining the objectives of the international entity (market share target, the pace of development, return of capital etc).

- study strategic alternatives (export directly, indirectly, direct investment, forms of cooperation and alliances);

- the realization of internationalization (forecasts of resources and affected the revenue estimate, the effective conduct of foreign operations, control);

The option of entering foreign markets cover the following aspects: the choice of strategy and the initial entry form is the largest of its strategy of entry, further strategies, and concrete strategies original form ways of entering foreign markets, strategy timing, refers to the staggered time of the entry strategy.

\footnotetext{
${ }^{1}$ Processing after V. Danciu, International Marketing, Economic Publishing House, Bucharest, 1998, p. 276.
} 


\section{Spectrum arrangements for access external markets}

The process of internationalization is generated by the strategic options which may call an entity. Every possible option is a strategic part of a whole organic growth of the firm commitment to the international markets.

Literature performed a multitude of groups of channels of entry into foreign markets. Among them we will stop on the group following ${ }^{2}$ indirect channels of entry (indirect exports), direct channels (export direct and direct investment), concerted input channels (alliances and cooperation).

When an entity decides to enter a foreign market, how practical that will choose depends on the degree of risk involved, the degree of control and that it expects profit and gain possible. Basically it is the following ways: indirectly export, licensing, export directly, joint - venture, direct investment.

Literature and reveals that the process of internationalization of business activities are progressive in nature, meaning that an entity which will involve for the first time on the international market in May elected as a present indirect, through specialized, that will gradually to build a presence significantly better in these markets and to engage directly by reducing the intervention of intermediaries.

Exports indirectly. Exports directly involve separating the functions of marketing of the production units autonomous. It is made by different categories of independent intermediaries, is a solution for entities that have not experienced International marketing and a first step to penetrate wider markets.

- Exports indirectly involve a minimum investment in international activities. Thus, the financial burden of the company is, in this case, the minimum entity having no practical need for additional financial resources to the transactions regular trading on the domestic market. Most of the time, intermediaries are the ones who really intended to finance the production of the company that are intended for export; intervention of financial intermediaries determined to resolve problems of liquidity. This form of penetration on foreign markets offers the possibility of obtaining significant market share, in a relatively short time.

- Appeal to specialized intermediaries is as a result its inability to get production experience on the international market because it has no direct contact with external clients. Loss points countries represented by the low price and high quality entail the proposal of less adverse conditions, the threat not to renew long-term contracts and risk exclusion from the market.

We can make abstraction of the risk of unmarketable goods or presenting prices, quality and design different from that of the loss of market share due to the limited possibilities of financial intermediaries or poor communication with potential borrowers.

Exports directly involve establishing a relationship directly with foreign entities. Direct export operations require a greater commitment in the export - adequate staff, management and prudent allocation of resources substantial.

Direct export has become a necessity for entities that choose the strategy of using its own brand, intends to adopt a policy established in trade and products require support post - sale.

Activity outlets abroad can be achieved through several ways: on your own, through specialized importers who sell on behalf of the entity, mandated by the people of the country of origin, opening their own points of sale in the country of destination.

Among the advantages of this form of marketing international find: financial costs and risks relatively low and the export control work. Also, the staff knows the characteristics of the product distribution and techniques sales, obtain the information necessary to adapt the 'package offer' (product, promotion, distribution techniques, prices) to the requirements of the market.

\footnotetext{
${ }^{2}$ V. Danciu, op. cit., p. 280.
} 
It can not be overlooked opportunity to compete with maximum efficiency, to coordinate and act promptly on combination coordinates marketing. It is in this way creates prerequisites for the use of pricing policy and promote flexible, to respond promptly to the current requirements of the market. The image of the product has earned and relationships with retailers become possible to adopt a selective policy.

Disadvantages export directly related mainly to reduce speed of penetration of the market arising from the difficulty of entering an unknown market that requires an initial investment which negatively affects the financial needs of the entity. Rigidity put their imprint on the production (by blocking a certain structure of it to achieve a fixed rate of production) or distribution (the risk of a fall of export parameters and of the need to resize the distribution network) and can compromise the profitability of the business.

Licensing. Is how to access external markets through the transfer of brand name or the right to use a patent or to use a process technology in exchange for a fee or copyright. It can take three forms: assignment of their actual license, license Cross (assumes a reciprocal transfer of licenses between two entities) and the franchising (by which a parent entity called the franchisor, grants to individuals, franchisee, the right to 'copy' business as a rule requiring certain rules and concurrent management systems).

Entity licensing obtain access to a market with foreign investment very low and in many cases benefit from the knowledge and investment market of a firm's local authorities. Entity that receives License gain access to foreign technology, with very little investment. This option is ideal in certain situations: the host country apply restrictions on imports and / or foreign investment, foreign market small, there are serious prospects of feed-back technology, technological change is so rapid that the licensing remains superior in this regard, there are opportunities for license ancillary processes, without requiring a license on fundamental technologies.

The granting of a license in May generate benefits such as access to markets difficult, low risk investment capital and low commitment of resources, obtaining information about product performance and activities competitors on various foreign markets, at modest cost, higher levels of delivery and serving on local markets F. Bradley believes that there are several reasons that a company would choose this option to permeate on foreign markets. The granting of a license may improve the cash flow for the company a grant. Because the technology allows a license to remove faster products on the market, the company enjoyed early advantage of a balance of positive cash flow. In addition, a license means development costs lower.

Sometimes, licensing is necessary because the specialized knowledge involving the use of the product (especially for products that require installation operations, providing further services, etc.). There is Also, territorial reasons that could make the granting of a license attractive way of entering foreign markets to target.

One of the biggest risks associated with the licensing contract is 'theft' of intellectual property by the licensee, because it may become a potential competitor. To avoid these situations, the licensing person may provide some ingredients or proprietary components in their own name, without which the product can not be achieved.

Licensing are other possible disadvantages. Power of the licensing person control over the licensee is lower than where the licensing person and would develop its own production capacity and for sale. In the event that the licensee enjoys very successful, it means that licensing person has virtually dropped to bigger profits, and when the license period ends, could discover that he created a single direct competitor.

Other drawbacks of allocating a license are: disclosure of competitive knowledge and experience accumulated over time can not control the license holder; passive interaction with the market; exclusion some export markets, organizing operations to place the license - the cost of adaptation, transfer and control. 
Franchise is a contractual arrangement whereby a person, losing grants another person, the beneficiary permission to use in its work of intellectual property rights or industrial transferor which they belong. Franchise is a form of licensing the franchise provides a standard package of products, systems and services management and franchise person market information, capital and personnel management.

Among the advantages of using franchise identified: rapid penetration on a foreign territory, franchise have access to the trade mark and related products, with the market value of upper management experience to franchise, can benefit from a loan from franchise advantageous in order to start business in the national etc.

It should be noted that the franchise is the use of generators and a series of challenges, among which we mention the following: franchisor has limited control over the activity franchise, suffer damage to the image of and its services in terms of problems in the work undertaken by the franchise; franchise profit is determined by the difference between inflows and income payments to franchising and by therefore bear residual risk of the local

Joint venture. Is a way of a partnership between local and one foreign, which often takes the form of a joint venture. The partnership aims, choosing the best combinations that could result from the contribution of knowledge market and management of material resources, financial and human resources and technology, which the two companies are investment. The formation of a joint venture may be necessary or desirable for the sake of economic or political.

Among the strengths of joint ventures emphasize: facilitating the transfer of technology, access to resources through the rapid diversification of production, as a means of corporate development, each partner concentrates its resources in an area of maximum advantage, eliminates the need for acquisition of international management skills, access to knowledge on the environment, achieve a competitive position more effective; ensuring local control on the attainment of jobs and technology transfer; good public relations, etc. control potential competition.

The combination of an equity joint venture includes certain risks, namely: misunderstandings on the steering management, commercial different cultures may lead to the emergence of conflicts on the manner of approach to business; transformation partners in competitors when they are revealing information that they were not accessible before, for the sake of protection of intellectual property. Moreover, the combination of capital may prevent a multinational company to implement certain policies of production and marketing worldwide.

Direct investment implies that the entity to open a subsidiary abroad to be independent under the strategic and financial, operating and selling it in his own name. Sometimes production abroad is aimed at ensuring the parts and subassemblies cheapest of the parent.

Foreign direct investment entity directly makes contact with external customers, even with the business environment for them. Firm enough, in terms of the international market, on a par with external customers, and the impact of these activities is felt to be the strongest. At the same time, financial investment firm is highest, and risks faced, unpublished.

It promotes the idea that can be identified several types of activities of multinational companies, depending on the motivation of investment which they dominate, namely: foreign direct investment in search of resources, markets; efficiency, foreign direct investment in search of strategic assets, other types of investments.

Search resources: upgrading the quality of resources and the existence of local partners willing to promote the joint use of knowledge and / or consumption of resources with high capital.

The search market: the increased need to be closer to users in sectors with high consumption of knowledge and the increasing importance of promotional activities undertaken by regional development agencies and local government.

Desiderate efficiency: increased role of governments in removing obstacles that stand in the way of restructuring of economic activity and facilitate the modernization of human resources, the 
existence of specialized industrial concentration (industrial parks), a private investment environment and a high degree of competitiveness and cooperation between firms.

Looking for strategic assets: favorable opportunities offered in exchange for localized tactical knowledge, the ideas and interactive learning, access to culture, institutions and different systems and applications and preferences different consumers.

Direct investment takes the form of acquisitions, mergers and investment on the empty seat.

Acquisitions consist of takeover / transfer of assets and operations of national companies or subsidiaries implanted in the host country by / for a foreign company, first becoming a subsidiary ${ }^{3}$ or branch ${ }^{4}$ of the latter.

It is believed that there are two major advantages of international acquisitions: on the one hand the company obtains assets that are already in use, so ratability is faster than for investment in fixed assets; on the other hand, the acquisition provides the company with a market share immediately, without any expansion of capacity.

The main limits of international acquisitions are cultural differences and language hinder the integration of the two management teams, wrong perceptions about the origin of the company concerned may lead errors in marketing, acquisition and takeover could mean some existing problems which may complicate the process of integrating new units in the international organization.

The merger is the operation whereby two or more entities to meet the financial position of generators to carry out the larger, which may provide, directly or indirectly, economic development.

In terms of how to achieve, the operation of the merger is structured as follows:

- merger by absorption in the ninth when a company continues to be absorbed and one or more companies;

- join the merger (merger) when it creates a new entity by the disappearance of the economic circuit of two other entities.

In literature ${ }^{5}$ and meets another form of merger, and de facto merger, which involves a combination of two or more independent operators, which, although retains personality legal, in the absence of a legal instrument, creating a group that is manifested competitive as a single economic entity.

Investments held on the empty units owned by overseas entity. Meets increasingly rare in international practice, but says that the main advantage of peak protection technologies, the possibility integration of production and operational effectiveness. On the opposite side is the high cost of investment, the period of time required for accommodation, political risks.

Strategic identified variants of practice, outlined above, with their strengths and weaknesses, involves activating the next parameters: the intensity of the risk of penetration by foreign markets, holding control of the business by foreign investors in the market of reference, the size of profits expected to be obtained as a result of processing penetrating foreign markets.

From another point of view, entry into the foreign markets is done through export strategies and contractual investment strategies, each with several variants ${ }^{6}$.

Success in international markets affects the choice of not only the potential growth of the entity, but also its ability to survive.

To exploit the competitive advantages identified in the foreign entity must follow these steps: (i) decision to extend the work to external markets, (ii) the selection of foreign markets, (iii) Selected international market segmentation, (iv) identifying the most profitable segments of

\footnotetext{
${ }^{3}$ Branch is a company established abroad which are legal, but is controlled by the parent company, which has totally or partially by its capital.

${ }^{4}$ Branch is a service company delocalised abroad without legal personality. Branch is organized, registered and operate according to local legislation and they operate on the basis autogestiunii economic-financial and foreign exchange.

${ }^{5}$ A. Tiron Tudor, ş.c., combining businesses. Mergers and acquisitions, Publishing Accent, Cluj-Napoca, 2005 , p. 31.

${ }^{6}$ F. Bradley, Marketing internațional, Publishing house Teora, Bucureşti, 2001, p. 270.
} 
consumers at international level, (v) the choice of modes of penetration in the markets concerned, (vi) development of marketing programs standard or adapted to the local environment for processing foreign markets, (vii) the creation of formulas organizational able to act locally and fulfilling the strategic objectives proposed.

These steps constitute, in fact, are components of marketing strategy through which the company may consider the international market, technologies used and the level of competitors, choosing the optimal relation Variation the products and services, the quality and geographically accessible space.

\section{Conclusions}

The alternatives the internationalization of entities is the result of a process whose early stage is the analysis of information about foreign markets, followed by the goals of internationalization.

From the strategic point of view, the essential differences between alternative ways of export consist of varying degrees of control offered by each option and said the necessary amount of resources committed. Most Good strategy remains, however, to be always in the forefront of innovation, turning human and material resources according to the requirements of the international market.

For entering international markets are absolutely necessary flexibility to structure the strategy so that it can adapt to market needs. The complexity lies in the difficulties that arise in dealing with debtors' customers, competition, intermediaries and governments; specificities of cultural and competitive,

Decisions that determine the evolution of a company involves recourse to the strategy, whose role is imminent in particular moments in history that stands, the building and change.

International affairs is 'a career disturbing' and a kind of 'romantic call' that comes irresistibly for many entrepreneurs who want to start a business or engage in a matter of maturity professional.

'Supreme test of competitive ability', an attractive challenge for a successful entity, is dependent on the level of commitment that an entity is willing to reach and level of control that it intends to established in the management of the operations carried out by foreign.

Information requirements and changing nature of human society 'oblige' the changing perception of what to do and when should be the why and how. Therefore, current conditions in the survival depend on adaptability to external market demands, the ability to choose the most efficient access external markets.

To find something must confront the most disparate ideas, to turn intellectual habits common to paradoxes look. Creation is in the clouds to obscure the contest ${ }^{8}$.

In our opinion to succeed means and dare to choose the most efficient way to pass the supreme test of competitive ability. To dare is to study the opportunities offered by the external market, put in balance the benefits and to disadvantages of each option for various 'maximin 2 the maximum effect - cost.

\section{References:}

1. Bradley F, Marketing internațional, Publishing House Teora, București, 2001.

2. Danciu V., Marketing strategic competitiv - o abordare internațională; Publishing House Economică, Bucureşti, 2004.

3. Danciu V., Marketing internațional; Publishing House Economică, Bucureşti, 1998.

\footnotetext{
${ }^{7}$ The expression belongs to Yip and was taken by F. Bradley, op. cit., p. 274

${ }^{8}$ Quote of belonging L. Rougier, taken after Florin Druta, Economic Motivation, Economic Publishing House, Bucharest, 1999, p. 261.
} 
4. Druță F., Motivația economică, Publishing House Economică, Bucureşti, 1999

5. Kotler Ph., Managementul marketingului, Publishing House Teora, Bucureşti, 1997.

6. Popa I., Tranzacții de comerț exterior, Publishing House Economică, Bucureşti, 2002.

7. Tiron Tudor A., ş.c., Combinări de întreprinderi. Fuziuni şi achiziții, Publishing House Accent, Cluj-Napoca, 2005. 